Article

\title{
Effect of Recycled Plastic Granules as a Partial Substitute for Natural Resource Sand on the Durability of SCC
}

\author{
Bala Rama Krishna Chunchu ${ }^{1}$ and Jagadeesh Putta ${ }^{2, *}$ \\ 1 Research scholar, Department of Structural and Geo-technical engineering, School of Civil Engineering, \\ Vellore Institute of Technology, Vellore-632014, India \\ 2 Professor, School of Civil Engineering, Vellore Institute of Technology, Vellore-632014, India \\ * Correspondence: p.jagadeesh@vit.ac.in; Tel.: +91-944-471-2064
}

Received: 9 June 2019; Accepted: 24 July 2019; Published: 27 July 2019

check for updates

\begin{abstract}
This investigation is focused on durability studies of binary blended self-compacting concrete (SCC) with the replacement effect of electronic plastic waste, namely high-impact polystyrene (HIPS) granules as partial sand. In the current investigation, for all the SCC mixes, cement is replaced with pozzolanic material fly ash in the binder content of $497 \mathrm{~kg} / \mathrm{m}^{3}$ and an adopted water-to-binder ratio of 0.36 . Durability properties such as porosity, water absorption, and sorptivity are assessed for the curing periods of 28 and 90 days on SCC specimens produced with HIPS ( $0 \%-40 \%$ replacement by volume of sand). Both surface and internal water absorption rates were found to be minimal for SCC with HIPS. Replacement of HIPS up to 30\% in SCC exhibited improved trends for all tests results. Reported durability parameter values were within permissible limits and revealed the excellent performance of HIPS in SCC. The optimum durability values can be attributed to the dense microstructure of SCC obtained with the combined effect of HIPS and fly ash. The continuous gradation of aggregates in the matrix reduced porosity due to the spherical shape of HIPS; additionally, the hydrophobicity of HIPS inhibits moisture migration in SCC. The additional benefits of fly ash, such as pozzolanic action and the filler effect at the interfacial transition zone (ITZ) are also major contributions to the long-term performance of durability. Electronic plastic waste replacement for fine aggregates in concrete compensates for the disposal problem and conserves natural sand.
\end{abstract}

Keywords: durability; high impact polystyrene; porosity; self-compacting concrete; sorptivity; water absorption

\section{Introduction}

The structure's serviceability depends on the durability that maintains the engineering properties of concrete, resisting severe environmental action. Durability depends mostly on the liquid's penetration capacity, which disturbs the chemical stability in the microstructure of concrete [1]. Thus, formed porosity is the measure of water saturation in the microstructure. The inter-connected pore structure allows a passage for fluid to be involved in the hydration process [2]. Permeability depends on the pore structure, micro-cracks in the paste and at the interfacial transition zone (ITZ) [3]. However, curing conditions are the main factors for pore structure. Temperature and duration of curing are the main factors for pore structure. The initial curing period plays an important role, in durability performance mainly, in the presence of mineral admixtures like fly ash for obtaining effective pozzolanic action in the concrete [4]. Pozzolanic materials can improve the microstructure in addition to plastic waste in concrete [5]. Admixtures reduce the air content by affecting the hydrophobicity of plastic aggregates in concrete [6]. However, high volume plastic content in concrete creates a high amount of porosity [7]. 
It has been found that the negligible water absorption experienced up to $10 \%$ replacement of plastic aggregates compared to the reference concrete [8]. The hygroscopic properties of self-compacting concrete (SCC) have been characterized by a decrease of water vapor adsorption capacity with the increasing percentage of plastic aggregates [9]. Increase in the amount of coarse plastic aggregate results in an exponential increment of water absorption in concrete [10]. Sorptivity is an easy method to determine the surface absorption rate. Moisture migration into pores through capillary suction can be evaluated. Total volume of capillary and gel pores can be estimated by weighing the water ingress into specimens from the soaking period [10-14]. In general, sorptivity and water absorption results follow a similar trend, though there is no such kind of exact relation [10]. Therefore, it has been found in studies that plastic waste in SCC can be replaced for fine aggregates for satisfying durable performance, though strength reduces [12-16]. However, flow-ability and slump retention capacity have performed better in SCC at a lower plastic replacement for sand [15]. Addition of admixtures such as fly ash in SCC enhance the durability due to pozzolanic activity and void filling that lead to better adhesion between cement paste and plastic aggregates $[17,18]$. Sorptivity coefficients, gas permeability coefficients, and chloride ion penetration of SCC with plastic waste have been shown to increase [19]. Alqahtani et al. have found that resistance to chloride ingress of concrete improves with the addition of plastic aggregates [20]. Admixtures enhance electrical resistance of SCC with plastic waste [21,22]. SCC samples with a higher percentage of polyethylene terephthalate (PET) particles retain a good load-bearing capacity against sulfuric acid attack. Hence, substituting partial sand with PET particles in SCC contributes to higher durability against sulfuric acid attack [23]. SCC with plastic aggregates has been evaluated for water absorption and sorptivity tests to study the resistance capacity of steel corrosion. Carbonation depth of concrete samples has been found to be higher for a higher amount of polyvinyl chloride (PVC) content. SCC with expanded polystyrene (EPS) has lower absorption and SCC mixtures with densities higher than $2000 \mathrm{~kg} / \mathrm{m}^{3}$ have a low corrosion risk. The air exclusion ratio has been found to be lower with a lower water/binder ratio [21]. Akçaözo $\breve{g l u}$ et al. have reported that a drying shrinkage of $56 \%$ was increased with a $100 \%$ PET aggregate [24]. Water absorption and sorptivity values of concrete with coarse plastic aggregates are higher than conventional concrete $[10,11]$. Though some studies are available which are related to the durability of concrete with plastic waste, research has to be developed based on influencing factors such as the shape and size of aggregates, treated plastic aggregates, curing conditions, favorable mix compositions of concrete, and the curing period, etc., [25]. Hence, the main objective of the current investigation was to examine the durability properties of spherical shaped high-impact polystyrene (HIPS) aggregates as a partial fine aggregate in binary blended SCC.

\section{Materials and Methods}

\subsection{Materials Used for the Development of SCC}

Ordinary Portland Cement 53 Grade was used in concrete for attaining good strength. Physical and chemical properties of ordinary Portland cement are explained in Tables 1 and 2. Coarse aggregates of sizes $12 \mathrm{~mm}$ and $10 \mathrm{~mm}$ were used in the ratio of 60:40 in SCC. The fineness modulus of coarse aggregates of $10 \mathrm{~mm}$ and $12 \mathrm{~mm}$ were 5.86 and 6.98, respectively. Natural river sand with a fineness modulus of 2.26 and a maximum size of $4.75 \mathrm{~mm}$ was partially replaced with plastic waste HIPS. All properties of aggregates and HIPS are compared in Table 3. Chemical composition of HIPS is presented in Table 4. Among the plastic wastes, HIPS is characterized by versatility, machine-ability, and excellent dimensional stability, and is often recommended for low strength structural applications, since it is economical. In India, HIPS is used in various products such as computer housing, and Audio-visual equipment parts, etc. Aforesaid plastic waste is recycled by shredding into required sizes and is utilized in food packaging, making toys, and plastic trays, etc. Its availability is in different sizes and shapes but in the current work, to replace fine aggregates, a commercially available particle size was selected in the range of $1 \mathrm{~mm}-4 \mathrm{~mm}$. Class F fly ash obtained from NTTPS Ibrahimpatnam, 
Vijayawada was used and its properties are explained in Table 5. Tap water was used in concrete mix preparation. Fosroc-based viscosity modifying agent and Conplast SP430 super plasticizer (sulfonated naphthalene polymer) was used and their properties are clearly mentioned in Table 6 . The percentage of dry material of super plasticizer and viscosity modifying agent used was $40 \%$. A scanning electronic microscopy image of HIPS and Energy dispersive analysis X-ray (EDAX) of HIPS are presented in Figures 1 and 2, respectively. The surface of HIPS is smooth in texture and spherical in shape, as shown in Figure 3. Methodology followed in determining durability of SCC is described in Figure 4.

Table 1. Physical properties of Ordinary Portland Cement (OPC) 53 grade cement.

\begin{tabular}{cccc}
\hline Properties & Test Result & Test Method & IS 12269 (1987) Requirements \\
\hline Normal consistency & $31 \%$ & IS 4031 (1988)-part 4 & - \\
Initial setting time (min) & 60 & IS 4031 (1988)-part 5 & Minimum time is 30 min \\
Final setting time (min) & 320 & IS 4031 (1988)-part 5 & Maximum time is $600 \mathrm{~min}$ \\
Specific gravity & 3.15 & IS 4031(1988)-part 11 & - \\
\hline Compressive strength (MPa) & & & \\
3 days & $30.82 \mathrm{MPa}$ & IS 4031 (1988)-part 6 & $27 \mathrm{MPa}$ \\
7 days & $49.50 \mathrm{MPa}$ & & $37 \mathrm{MPa}$ \\
28 days & $58.34 \mathrm{MPa}$ & & $53 \mathrm{MPa}$ \\
\hline
\end{tabular}

Table 2. Chemical properties of OPC 53 grade cement.

\begin{tabular}{ccc}
\hline Particulars & $\begin{array}{c}\text { Percentage of Chemical } \\
\text { Composition (\%) }\end{array}$ & IS:12269-1987Recommendations \\
\hline Lime $(\mathrm{CaO})$ & 61.85 & \\
\hline Silica $\left(\mathrm{SiO}_{2}\right)$ & 20.07 & \\
\hline Iron oxide $\left(\mathrm{Fe}_{2} \mathrm{O}_{3}\right)$ & 4.62 & Not more than $6.0 \%$ \\
\hline Alumina $\left(\mathrm{Al}_{2} \mathrm{O}_{3}\right)$ & 5.32 & Maximum content is $3.0 \%$ when $\mathrm{C}_{3} \mathrm{~A}>5.0 ;$ \\
\hline Magnesia $(\mathrm{MgO})$ & 0.83 & Maximum content is $2.5 \%$ when $\mathrm{C}_{3} \mathrm{~A}<5.0$ \\
\hline Sulfuric anhydride $\left(\mathrm{SO}_{3}\right)$ & 2.50 & 0.80 to 1.02 \\
\hline Lime saturation factor & 0.91 & Minimum is 0.66 \\
\hline CaO-0.7SO $/ 2.8 \mathrm{SiO}_{2}+1.2 \mathrm{Al}_{2} \mathrm{O}_{3}+0.65 \mathrm{Fe}_{2} \mathrm{O}_{3}$ & 1.18 & Maximum content is $0.1 \%$ \\
\hline Ratio of alumina/iron oxide & 0.0028 & \\
\hline Chloride content &
\end{tabular}

Table 3. Properties of coarse, fine and high-impact polystyrene aggregate

\begin{tabular}{cccc}
\hline \multirow{2}{*}{ Aggregate Property } & \multicolumn{3}{c}{ Aggregate Type } \\
\cline { 2 - 4 } & Coarse Aggregate & Fine Aggregate & HIPS Aggregate \\
\hline Specific gravity & 2.7 & 2.6 & 1.04 \\
Water absorption $(\%)$ & $0.3 \%$ & $1 \%$ & Negligible \\
Bulk density $\left(\mathrm{kg} / \mathrm{m}^{3}\right)$ & 1656 & 1609 & 650 \\
Size of aggregate $(\mathrm{mm})$ & $12 \mathrm{~mm}$ and $10 \mathrm{~mm}$ in $60: 40$ ratio & Less than 4.75 & $1 \mathrm{~mm}-4 \mathrm{~mm}$ \\
\hline
\end{tabular}

Table 4. Chemical composition of HIPS.

\begin{tabular}{ccc}
\hline Element & Weight $\%$ & Atomic\% \\
\hline C K & 82.13 & 87.10 \\
O K & 14.73 & 11.73 \\
Si K & 1.32 & 0.60 \\
Ca K & 1.82 & 0.58 \\
Total & 100.00 & \\
\hline
\end{tabular}


Table 5. Properties of fly-ash.

\begin{tabular}{ccc}
\hline & \multicolumn{2}{c}{ Chemical Properties } \\
\hline Class F Fly Ash Particulars & Chemical Composition (\%) & Recommendations According to ASTM C 618 \\
\hline Silica $\left(\mathrm{SiO}_{2}\right)$ & 60.5 & \\
Alumina $\left(\mathrm{Al}_{2} \mathrm{O}_{3}\right)$ & 30.8 & \\
Iron oxide $\left(\mathrm{Fe}_{2} \mathrm{O}_{3}\right)$ & 3.6 & $\mathrm{SiO}_{2}+\mathrm{Al}_{2} \mathrm{O}_{3}+\mathrm{Fe}_{2} \mathrm{O}_{3}>70$ \\
Lime $(\mathrm{CaO})$ & 1.4 & \\
Magnesia $(\mathrm{MgO})$ & 0.91 & \\
Sulfuric anhydride $\left(\mathrm{SO}_{3}\right)$ & 0.14 & Maximum of 5.0 \\
$\mathrm{~K}_{2} \mathrm{O}+\mathrm{Na}_{2} \mathrm{O}$ & 1.1 & \\
Loss on ignition & 0.29 & \\
& Physical Properties & \\
\hline Specific gravity & 2.2 & Minimum of $225 \mathrm{~m}^{2} / \mathrm{kg}$ \\
\hline Fineness $\left(\mathrm{m}^{2} / \mathrm{kg}\right)$ & 320 &
\end{tabular}

Table 6. Properties of chemical admixtures.

\begin{tabular}{ccc}
\hline Particulars & $\begin{array}{c}\text { Test Results of Super-Plasticizer } \\
\text { FOSROC Conplast SP430 }\end{array}$ & $\begin{array}{c}\text { Test Results of FOSROC } \\
\text { Viscosity Modifying Agent }\end{array}$ \\
\hline $\begin{array}{c}\text { Specific gravity } \\
\text { Color }\end{array}$ & 1.20 & 1.09 \\
Solid content $(\%)$ & Brown & White \\
Quantity (\%) by & 40 & 40 \\
cementitious weight & 0.9 & 0.2 \\
Main component & Sulfonated naphthalene polymers & Poly-carboxylate ether \\
\hline
\end{tabular}

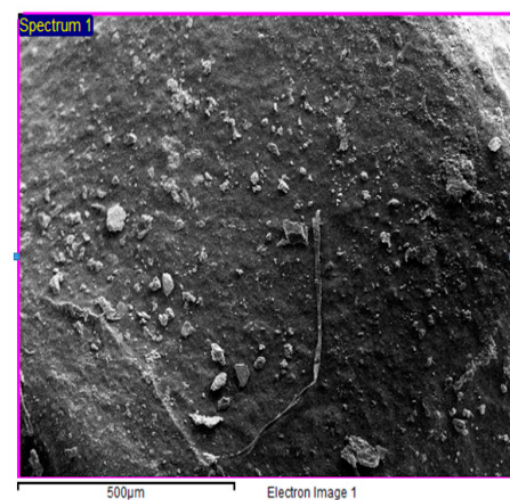

Figure 1. SEM image of high-impact polystyrene.

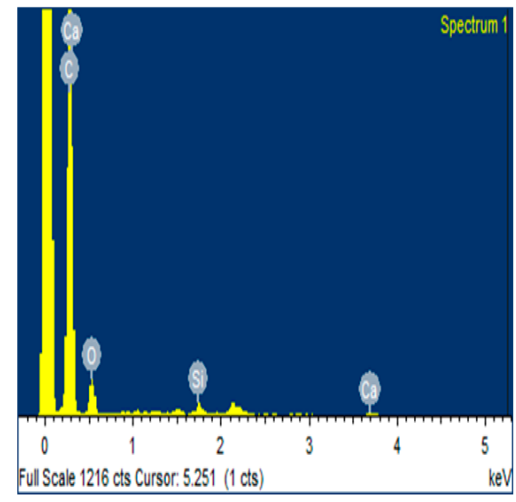

Figure 2. Energy-dispersive analysis X-ray (EDAX) image of HIPS. 


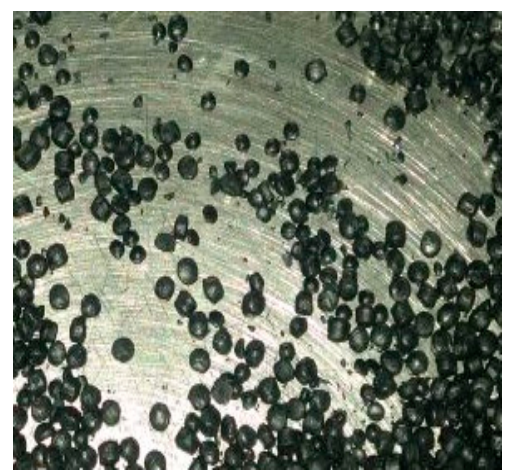

Figure 3. High-impact polystyrene granules.

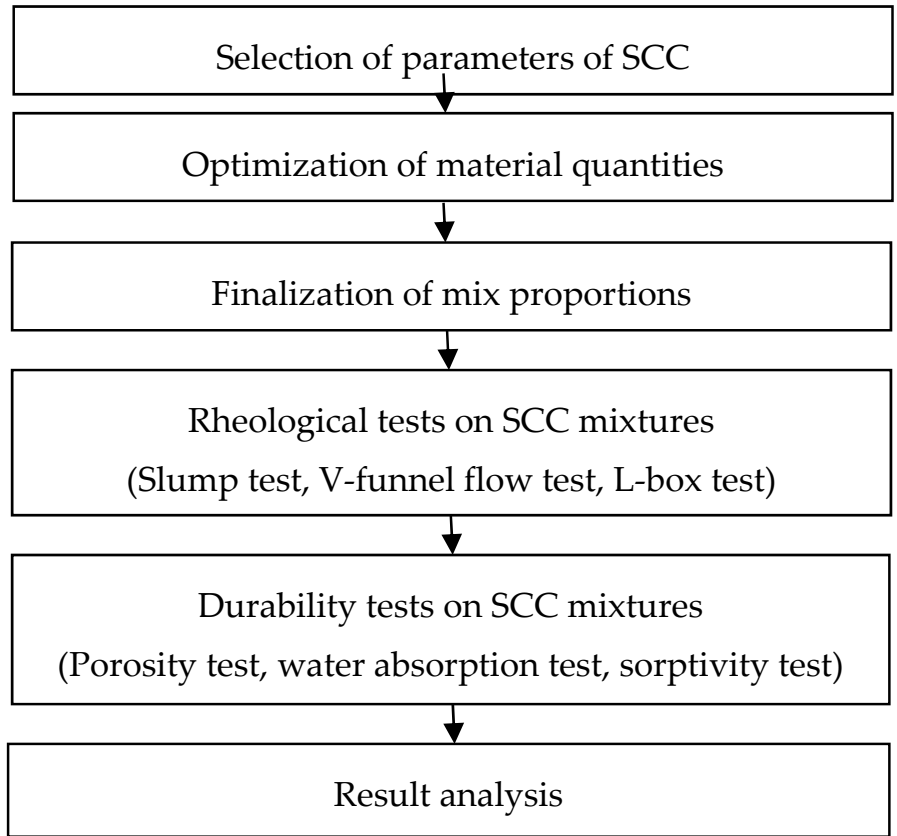

Figure 4. Methodology followed in determining durability of self-compacting concrete (SCC).

\subsection{Mix Proportions}

SCC was produced with binder content of $497 \mathrm{~kg} / \mathrm{m}^{3}$, replacing cement with $30 \%$ fly ash by weight and sand with HIPS (10\%-40\%) by volume. The fine aggregate was $54.13 \%$ (by volume). Coarse aggregates used were $12 \mathrm{~mm}$ of $28.08 \%$ (by weight) and $10 \mathrm{~mm}$ of $18.72 \%$ (by weight). Water to binder ratio of 0.36 was used for all SCC mixes. SCC replaced with only $30 \%$ fly ash was used as a reference mix. SCC of $\mathrm{M}_{30}$ grade was used to determine the durable properties. Optimized material quantities are given in Table 7. Flow-ability and mix proportions used in SCC production are shown in Table 8. 
Table 7. Optimization of material quantities for SCC mix.

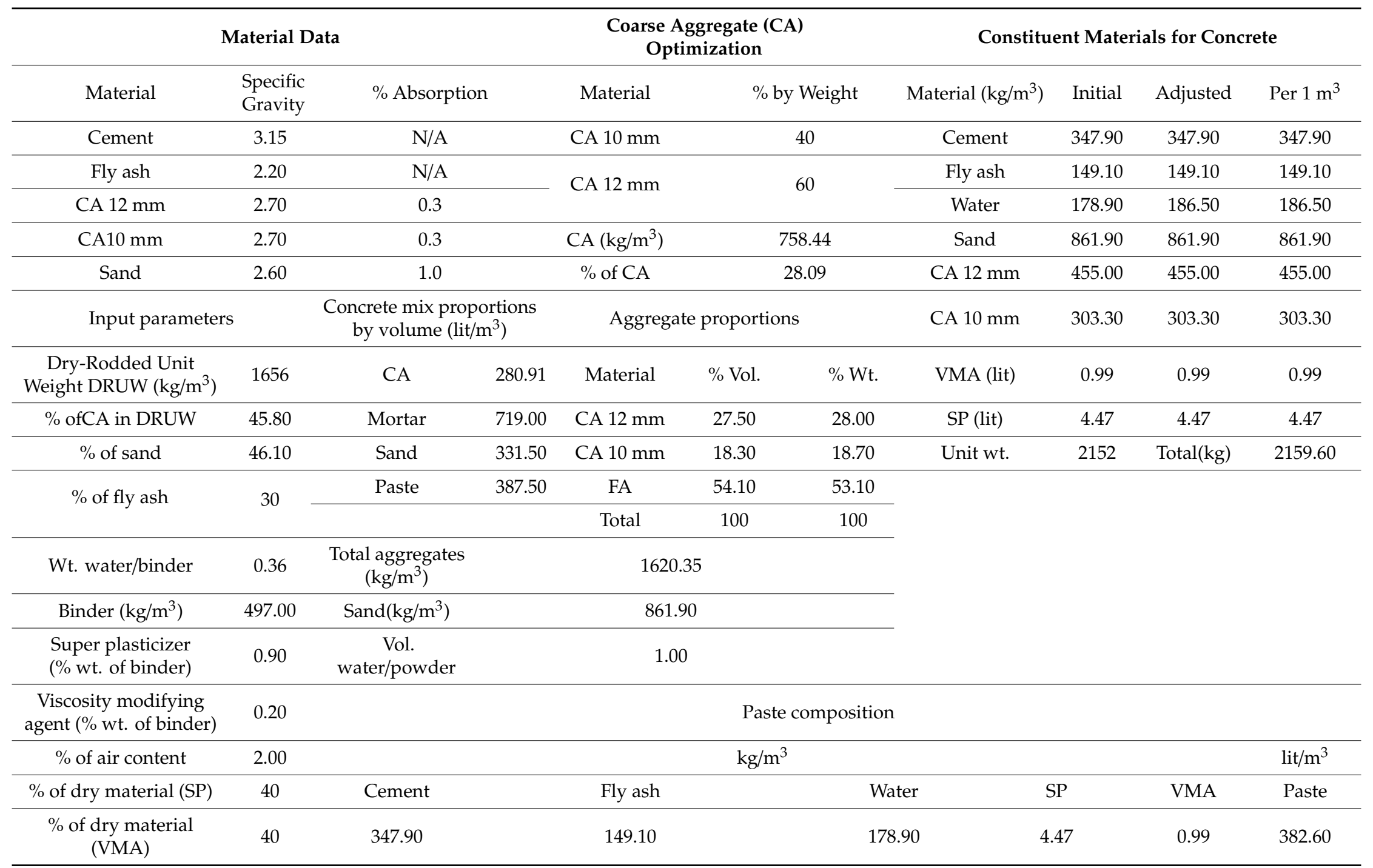


Table 8. Mix proportions used and flow-ability performance with variation of HIPS aggregate.

\begin{tabular}{|c|c|c|c|c|c|c|c|c|c|}
\hline \multirow[b]{2}{*}{$\begin{array}{l}\text { Cement } \\
\left(\mathrm{kg} / \mathrm{m}^{3}\right)\end{array}$} & \multirow{2}{*}{$\begin{array}{c}\text { Fly Ash }(30 \% \text { by } \\
\text { Wt. of Cement) } \\
\left(\mathrm{kg} / \mathrm{m}^{3}\right)\end{array}$} & \multicolumn{2}{|c|}{$\begin{array}{c}\text { Coarse Aggregate } \\
\left(\mathrm{kg} / \mathrm{m}^{3}\right)\end{array}$} & \multirow[b]{2}{*}{$\underset{\left(\mathrm{kg} / \mathrm{m}^{3}\right)}{\text { Sand }}$} & \multirow[b]{2}{*}{$\begin{array}{c}\text { HIPS } \\
(\%)\end{array}$} & \multirow[b]{2}{*}{$\begin{array}{l}\text { HIPS } \\
\left(\mathrm{kg} / \mathrm{m}^{3}\right)\end{array}$} & \multicolumn{3}{|c|}{ Flow-Ability } \\
\hline & & $12 \mathrm{~mm}$ & $10 \mathrm{~mm}$ & & & & $\begin{array}{l}\text { Slump } \\
(\mathrm{mm})\end{array}$ & $\begin{array}{l}\text { V-Funnel } \\
\text { Flow Time } \\
\text { (sec) }\end{array}$ & $\begin{array}{c}\text { L-Box } \\
\left(\mathrm{h}_{2} / \mathrm{h}_{1}\right) \\
\text { ratio }\end{array}$ \\
\hline 347.90 & 149.10 & 455.07 & 303.38 & 861.69 & 0 & 0.00 & 598 & 9.80 & 0.83 \\
\hline 347.90 & 149.10 & 455.07 & 303.38 & 776.18 & 10 & 34.48 & 659 & 9.20 & 0.86 \\
\hline 347.90 & 149.10 & 455.07 & 303.38 & 690.13 & 20 & 69.01 & 690 & 8.60 & 0.88 \\
\hline 347.90 & 149.10 & 455.07 & 303.38 & 603.85 & 30 & 103.51 & 723 & 8.00 & 0.89 \\
\hline 347.90 & 149.10 & 455.07 & 303.38 & 517.53 & 40 & 138.00 & 642 & 10.3 & 0.78 \\
\hline
\end{tabular}

\subsection{Test Procedure}

\subsubsection{Porosity Test on SCC Specimen}

All SCC cube specimens of size $100 \times 100 \times 100 \mathrm{~mm}$ were used to determine the porosity. As shown in Figure 5, a porosity test at the curing age of 28 days was conducted according to ASTM C642-13.

Oven-dry mass: The concrete specimen was placed in an oven at $110^{\circ} \mathrm{C}$ until constant mass was attained. The specimen from the oven was removed and allowed to air dry. The mass of the dried specimen was obtained and designated as $A$.

Saturated specimen mass: The concrete specimen was immersed in water for not less than $48 \mathrm{~h}$ till its two successive masses of surface-dried sample values were the same. The determined mass was designated as $B$.

Saturated mass after boiling: The concrete specimen was placed in water for boiling for up to $5 \mathrm{~h}$ and allowed to air dry. The mass obtained was designated as $C$.

Immersed apparent mass: The specimen with apparent mass in water was determined using a digital weighing machine and finally this apparent mass of specimen was designated as $D$.

Porosity was calculated as shown in Equations (1)-(3) and tested as given in Figure 5.

$$
\begin{aligned}
& \text { Dry bulk density }=\rho\left[\frac{\mathrm{A}}{\mathrm{C}-\mathrm{D}}\right]=\mathrm{g}_{1} \\
& \text { Apparent density }=\rho\left[\frac{\mathrm{A}}{\mathrm{A}-\mathrm{D}}\right]=\mathrm{g}_{2}
\end{aligned}
$$

Volume of permeable pore space voids $=100\left[\frac{g_{2}-g_{1}}{g_{2}}\right]$

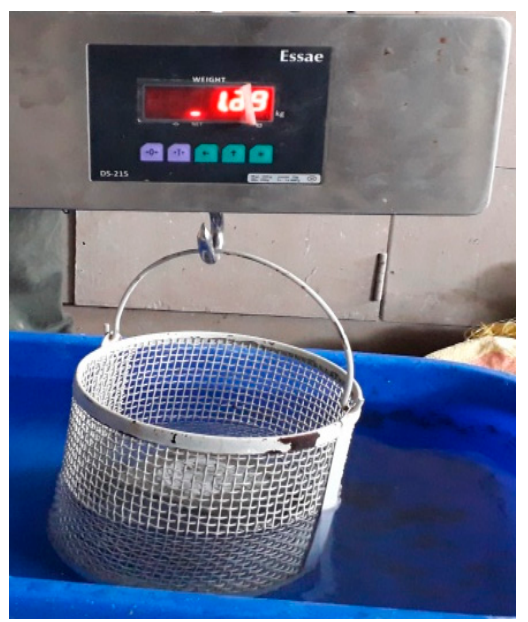

Figure 5. Determination of apparent density for porosity test. 


\subsubsection{Water Absorption Test on SCC Specimen}

All SCC cube specimens of size $100 \mathrm{~mm} \times 100 \mathrm{~mm} \times 100 \mathrm{~mm}$ were tested to determine the water absorption according to ASTM C642-13 [26]. A water absorption test at the curing period of 28 and 90 days was performed as shown in Figure 6. Air dried specimens were placed at $100{ }^{\circ} \mathrm{C}$ until a constant weight $(x$ in $\mathrm{kg}$ ) was obtained. Specimens were immersed in water again and then the saturated surface dried specimens weighted ( $\mathrm{y}$ in $\mathrm{kg}$ ). Thus, water absorption $(\%)$ was calculated according to Equation (4).

$$
\text { Water absorption }(\%)=\frac{100(y-x)}{x}
$$

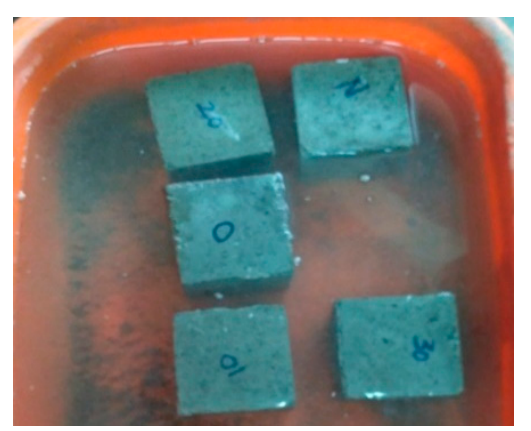

Figure 6. SCC specimens with HIPS in water tank.

\subsubsection{Sorptivity Test on SCC Specimens}

A sorptivity test was conducted according to ASTMC1585-13 [27] to determine the rate of water absorption. It measured the change in mass of specimen with respect to time by immersing one surface in a water container to a depth of 3-5 mm. Capillary suction is high during the initial contact of water for unsaturated concrete. Cylindrical specimens of $100 \mathrm{~mm}$ diameter and $50 \mathrm{~mm}$ depth were sealed with covers except for the bottom surface, and weights were measured. The specimen was immersed in the water container for up to $3-5 \mathrm{~mm}$ of the concrete bottom surface. The mass change was recorded from the initial contact of water to different time intervals as given in Table 6 . The sorptivity was tested as given in Figure 7a,b and was calculated using Equations (5) and (6). Time intervals with tolerance limits are shown in Table 9.

$$
\begin{aligned}
& S=\frac{I}{\sqrt{ } t} \\
& I=\frac{m}{\sqrt{ } t}
\end{aligned}
$$

where, $\mathrm{S}=$ the sorptivity coefficient $(\mathrm{mm} / \sqrt{\mathrm{min}}), I=$ the water absorption per unit concrete surface area $(\mathrm{mm}), m_{t}=$ the change in mass of specimen (grams) w.r.t. time(min), $a=$ the exposed area of the specimen $\left(\mathrm{mm}^{2}\right), d=$ density of water $\left(\mathrm{g} / \mathrm{mm}^{3}\right)$, and $t=$ time at weight measured (min). 
Table 9. Sorptivity time intervals according to ASTM C1585-13.

\begin{tabular}{cc}
\hline Time (sec) & Tolerance (+/-) \\
\hline $60 \mathrm{~s}$ & $2 \mathrm{~s}$ \\
$5 \mathrm{~min}$ & $10 \mathrm{~s}$ \\
$10 \mathrm{~min}$ & $2 \mathrm{~min}$ \\
$20 \mathrm{~min}$ & $2 \mathrm{~min}$ \\
$30 \mathrm{~min}$ & $2 \mathrm{~min}$ \\
$60 \mathrm{~min}$ & $2 \mathrm{~min}$ \\
Every hour, up to 6 h measurement on first day & $5 \mathrm{~min}$ \\
Once a day, up to 3 days & $2 \mathrm{~h}$ \\
Day 4 to 7, three measurements 24 h apart & $2 \mathrm{~h}$ \\
Day 7 to 9, one measurement & $2 \mathrm{~h}$ \\
\hline
\end{tabular}

The initial rate of water absorption $(\mathrm{mm} / \sqrt{ } \mathrm{min})$ was the slope of the best fit line plotted between $I$ vs. $(\sqrt{ } \mathrm{min})$, taking values from $1 \mathrm{~min}$ to $60 \mathrm{~min}$. The secondary rate of water absorption $(\mathrm{mm} / \sqrt{ } \mathrm{s}) \mathrm{was}$ the slope of the best fit line between $I$ vs. $(\sqrt{ } \mathrm{min})$, taking values from 1 day to 7 days.

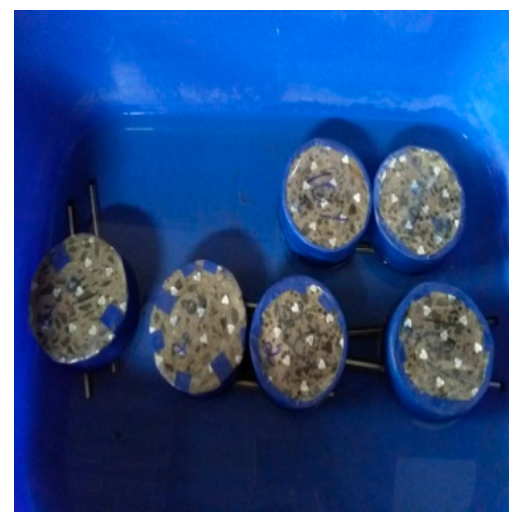

(a)

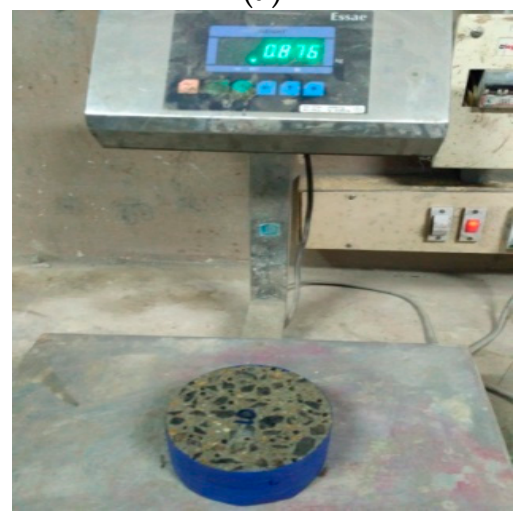

(b)

Figure 7. (a)SCC specimens immersed in water during sorptivity test; (b)weighing SCC specimens with exposed bottom surface.

\section{Result and Discussion}

\subsection{Effect of HIPS Aggregate on Porosity of SCC}

Due to rheological enhancement, SCC compacted well with an existing continuous gradation among the matrix and hence porosity reduced up to $30 \%$ replacement. Ruiz-Herrero et al. have reported that $200 \%$ and $140 \%$ higher porosity were identified in concrete at 28 days with $20 \%$ of polyethylene (PET) and 20\% Poly vinyl chloride (PVC) [28]. Similarly, porosities of conventional 
concrete and concrete with coarse electronic waste of $15 \%$ PET were $5.35 \%$ and $7.65 \%$ [11]. In the current investigation, porosity values were obtained of less than $5 \%$ for all curing periods. SCC with HIPS exhibited less porosity up to $30 \%$ replacement compared to $0 \%$ replacement, since HIPS particle size ranging $1 \mathrm{~mm}-4 \mathrm{~mm}$ filled the voids wherein fine aggregates and coarse aggregates couldn't fill voids interlocking among the matrix. Porosity reduced up to 30\% HIPS replacement and abruptly changed at $40 \%$ in all curing ages, as shown in Figure 8 . Hence, a high amount of HIPS replacement from $40 \%$ onwards did not help in any property enhancement due to the existence of more plastic per unit volume of concrete, weakening the particle packing density. Water absorption mainly depends on the amount of porosity available in concrete and it was observed that porosity reduced for all curing ages up to $30 \%$ of HIPS replacement.

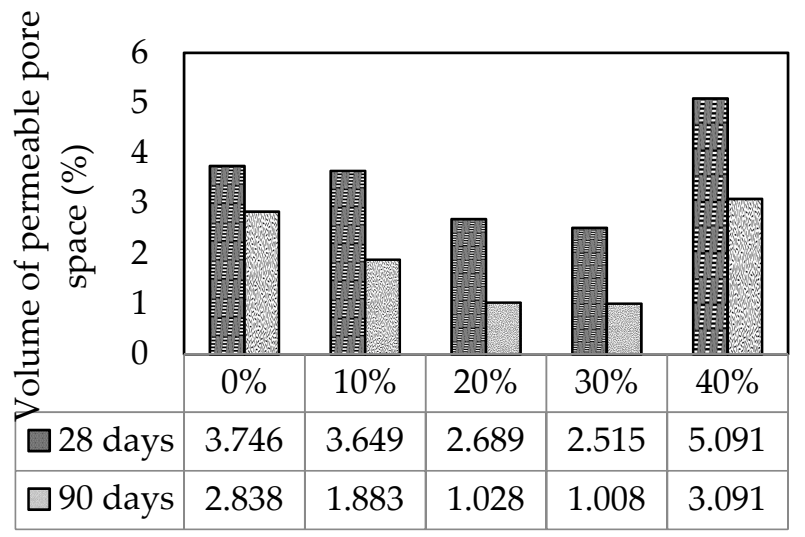

Figure 8. Porosity variations with different \% of HIPS replacement.

\subsection{Effect of HIPS Granules in Water Absorption of SCC}

Water absorption of conventional concrete and concrete with coarse electronic waste of $15 \%$ PET has been found to be $2.12 \%$ and $3.56 \%$, respectively [11]. Almost $100 \%$ higher water absorption has been noticed in concrete with $15 \%$ coarse e-plastic compared to the reference concrete [10]. Coppola et al. have replaced sand with plastic aggregates at $10 \%, 25 \%$, and $50 \%$ in producing lightweight concrete. It has been found that the same amount of absorption as conventional concrete with $10 \%$ sand replacement and about $117 \%$ higher water absorption was found for $50 \%$ sand replacement [29]. Similarly, water absorption of SCC with 15\% fine PET aggregate and 30\% fly ash has been found to be $7.9 \%$ [28]. Water absorption values of SCC specimens after curing of 28 days and 90 days are given in Figure 9. Water absorption reduced with an increase in percentage replacement of HIPS of up to $30 \%$. Water absorption acceptance criteria are shown in Table 10 as per CEB-FIP, 1989 [29].

Table 10. Acceptance criteria according to CEB-FIP, 1989.

\begin{tabular}{cc}
\hline Water Absorption (\%) & Performance \\
\hline$>5 \%$ & Poor \\
$3 \%-5 \%$ & Average \\
$<3 \%$ & Good \\
\hline
\end{tabular}

Water absorption values of SCC with HIPS after the curing period of 28 days were $3.53 \%, 3.3 \%$, $3.11 \%$, and $4.96 \%$ for $10 \%, 20 \%, 30 \%$, and $40 \%$, respectively. The aforesaid values were in between $3 \%-5 \%$ and the performance was found to be average in water absorption at the age of 28 days. Water absorption increased abruptly after 30\% replacement of HIPS because minute cracks or voids existed especially at the ITZ, though fly ash acted as filler. However, water absorption with HIPS up to $30 \%$ replacement exhibited better performance than the reference concrete absorption value, i.e., $3.89 \%$. The major reason for the reduction in water absorption was the water-repellent nature of HIPS. 
Pozzolanic activity resisted the water absorption in longer curing periods, i.e., 90 days. All the test values obtained at 90 days were showing good performance of up to $30 \%$ HIPS content, i.e., less than $3 \%$. High volume replacement increased the porosity due to the smooth texture and spherical shape of HIPS compared to natural sand.

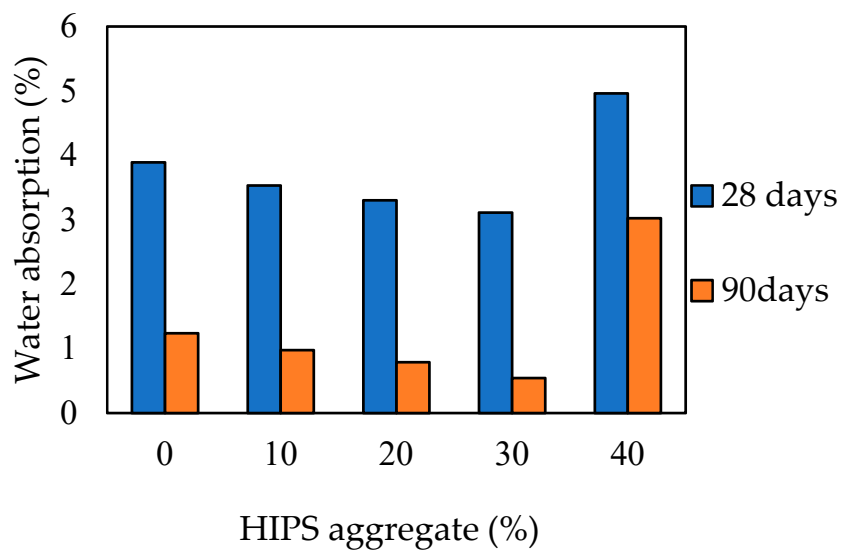

Figure 9. Water absorption (\%) of SCC mixes with HIPS aggregate (\%) at different curing periods.

\subsection{Effect of HIPS Granuleson Sorptivity of SCC}

Sorptivity values of conventional concrete and concrete with coarse electronic waste of $15 \%$ PET were obtained as 0.058 and $0.087 \mathrm{~mm} / \sqrt{ } \mathrm{min}$ [11]. Sorptivity of concrete with coarse HIPS aggregates (10 to $50 \%$ ) varied between 0.048 and $0.064 \mathrm{~mm} / \sqrt{ } \mathrm{min}, 0.0466$ and $0.0544 \mathrm{~mm} / \sqrt{ } \mathrm{min}$, and 0.0426 and $0.0515 \mathrm{~mm} / \sqrt{ } \min$ for 7,28 , and 90 days, respectively. However, sorptivity values of the control concrete varied from $0.039 \mathrm{~mm} / \sqrt{ } \mathrm{min}$ to $0.038 \mathrm{~mm} / \sqrt{ } \mathrm{min}$ for 7 to 90 days, respectively [10]. No data exists related to sorptivity values of SCC with fine plastic aggregates and hence it is a valuable attempt to test the sorptivity performance of binary blended SCC with partial fine plastic aggregates. Sorptivity values are shown in Figure 10 at the curing periods of 28 days and 90 days. It was observed that sorptivity values were reduced up to $30 \%$ replacement of sand with HIPS aggregate. Reduction in sorptivity was primarily due to the sufficient compaction attained with the enhanced rheology of SCC by pozzolanic fly ash and HIPS. Moreover, the long term pozzolanic reaction of fly ash had a great influence on the reduction of sorptivity at 90 days compared to 28 days. As the curing period increased, the sorptivity values decreased due to reduction of pores at the interfacial zone. From 28 to 90 days, the sorptivity values reduced considerably. Sorptivity values were $0.065,0.045,0.034$, and $0.028 \mathrm{~mm} / \sqrt{ } \mathrm{min}$ for $0 \%$, $10 \%, 20 \%$, and $30 \%$ at 28 days curing and $0.042,0.036,0.030$, and $0.021 \mathrm{~mm} / \sqrt{ } \mathrm{min}$ at 90 days curing from $0 \%-30 \%$ replacement, respectively. For both water absorption and sorptivity testing results showed the same trend line; however, this is not mandatory [10]. The aforesaid results reveal SCC with HIPS is more durable compared to reference SCC concrete. 


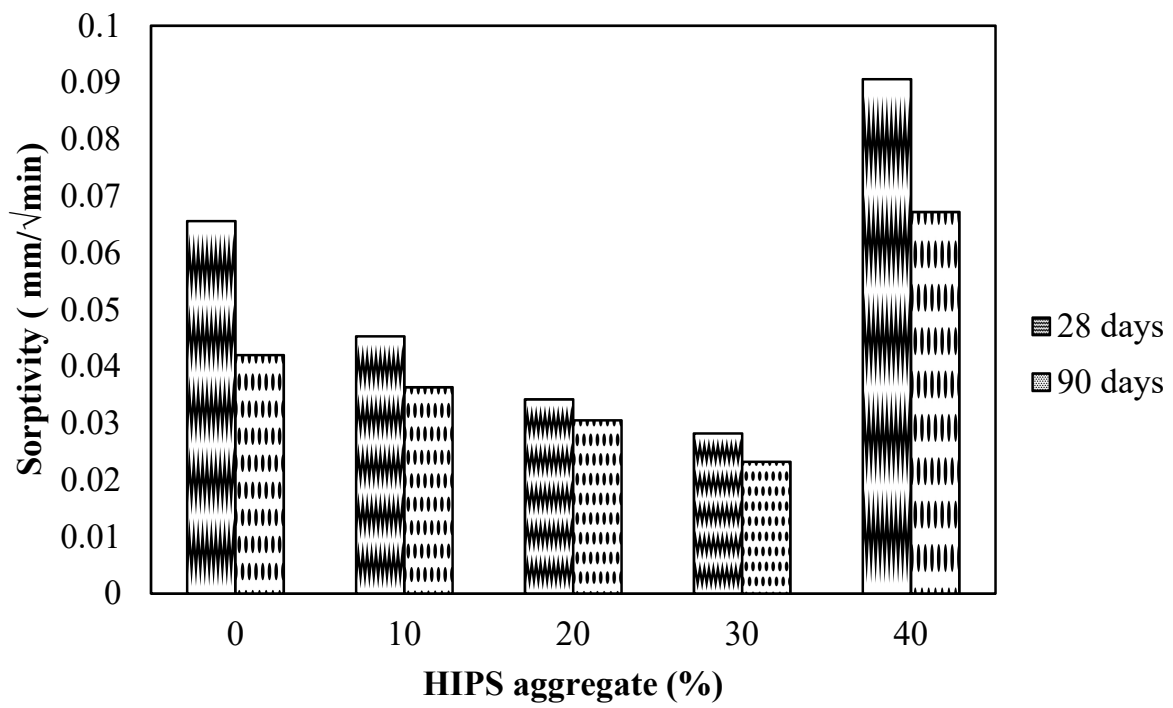

Figure 10. Sorptivity of SCC with respect to \% variation of HIPS aggregates at $1 \mathrm{~h}$ time period.

\section{Conclusions}

The following are the conclusions drawn regarding the combined effects of fly ash and HIPS granules on self-compacting concrete:

- Good compaction was attained with the existence of continuous gradation in the concrete matrix up to $30 \%$ HIPS replacement for fine aggregate in SCC. Hence, porosity was reduced about $30 \%$ due to enhanced rheology in SCC.

- Performance of HIPS in water absorption was found to be average and satisfactory $(<5 \%)$. Only $20 \%$ of water absorption reduced at $30 \%$ of HIPS replacement in place of fine aggregate for SCC compared to reference concrete. Sorptivity values were reduced for concrete with $30 \%$ of HIPS replacement of fine aggregate for all curing ages. Reduction of water absorption and sorptivity values was higher for the 90 days compared to the 28 days curing period due to pozzolanic activity.

- The shape, size, and inert nature of HIPS aggregates resemble the properties of sand and it helps for SCC in achieving excellent durable performance. Recycled HIPS can be replaceable up to $30 \%$ for natural river sand for producing eco-friendly, durable, and flow-able concrete.

Author Contributions: B.R.K.C. and J.P. defined the goals of the study. All authors performed the literature study. All authors have written the manuscript and commented on the final draft.

Funding: No specific funding was received for this research.

Conflicts of Interest: The authors confirm that there is no conflict of interest.

\section{References}

1. Mehta, P.K.; Monteiro, P. Concrete: Microstructure, Properties and Materials; McGraw-Hill: New York, NY, USA, 2006.

2. Ramli, M.; Tabassi, A.A. Effects of polymer modification on the permeability of cement mortars under different curing conditions: A correlational study that includes pore distributions, water absorption and compressive strength. Constr. Build. Mater. 2012, 28, 561-570. [CrossRef]

3. De Schutter, G. Evaluation of water absorption of concrete as a measure for resistance against carbonation and chloride migration. Mater. Struct. 2004, 37, 591-596. [CrossRef]

4. Tasdemir, C. Combined effects of mineral admixtures and curing conditions on the sorptivity coefficient of concrete. Cem. Concr. Res. 2003, 33, 1637-1642. [CrossRef] 
5. Nik, A.S.; Omran, O.L. Estimation of compressive strength of self-compacted concrete with fibers consisting nano-SiO 2 using ultrasonic pulse velocity. Constr. Build. Mater. 2013, 44, 654-662.

6. Jacob-Vaillancourt, C.; Sorelli, L. Characterization of concrete composites with recycled plastic aggregates from postconsumer material streams. Constr. Build. Mater. 2018, 182, 561-572. [CrossRef]

7. Gu, L.; Ozbakkaloglu, T. Use of recycled plastics in concrete: A critical review. Waste Manag. 2016, 51, 19-42. [CrossRef]

8. Coppola, B.; Courard, L.; Michel, F.; Incarnato, L.; Scarfato, P.; Di Maio, L. Hygro-thermal and durability properties of a lightweight mortar made with foamed plastic waste aggregates. Constr. Build. Mater. 2018, 170, 200-206. [CrossRef]

9. Záleská, M.; Pavlíková, M.; Pokorný, J.; Jankovský, O.; Pavlík, Z.; Černý, R. 'Structural, mechanical and hygrothermal properties of lightweight concrete based on the application of waste plastics. Constr. Build. Mater. 2018, 180, 1-11. [CrossRef]

10. Kumar, K.S.; Premalatha, P.V.; Baskar, K. Evaluation of Transport Properties of Concrete Made with E-Waste Plastic. J. Test. Eval. 2016, 45, 1849-1853.

11. Lakshmi, R.; Nagan, S. Investigations on durability characteristics of e-plastic waste incorporated concrete. Asian J. Civ. Eng. 2011, 12, 773-787.

12. Krishna, C.B.R.; Jagadeesh, P. Influence of Admixtures on Plastic Wastes in an Eco-Friendly Concrete A Review. Int. J. Civ. Eng. Technol. 2017, 8, 388-397.

13. Krishna, C.B.R.; Jagadeesh, P. Durability studies on Self-Compacting Concrete replacing fine aggregate partially with High impact polystyrene. Int. J. Eng. Adv. Technol. 2019, 8, 75-79.

14. Krishna, C.B.R.; Jagadeesh, P. Strength and Durability assessment of binary blended Self-Compacting Concrete replacing partial sand with electronic plastic waste. Int. J. Innov. Technol. Explor. Eng. 2019, 8, 107-111.

15. Krishna, C.B.R.; Jagadeesh, P. Rheological and Strength Behavior of Binary Blended SCC Replacing Partial Fine Aggregate with Plastic E-Waste as High Impact Polystyrene. Buildings 2019, 9, 50.

16. Krishna, C.B.R.; Jagadeesh, P. Fresh and Hardened Properties of Self-Compacting Concrete Replacing Fine Aggregate with High Impact Polystyrene Plastic Granules. Int. J. Civ. Eng. Technol. 2018, 9, 831-838.

17. Yang, S.; Yue, X.; Liu, X.; Tong, Y. Properties of self-compacting lightweight concrete containing recycled plastic particles. Constr. Build. Mater. 2015, 84, 444-453. [CrossRef]

18. Hama, S.M.; Hilal, N.N. Fresh properties of self-compacting concrete with plastic waste as partial replacement of sand. Int. J. Sustain. Built Environ. 2017, 6, 299-308. [CrossRef]

19. Faraj, R.H.; Sherwan, A.F.H.; Daraei, A. Mechanical, fracture and durability properties of self-compacting high strength concrete containing recycled polypropylene plastic particles. J. Build. Eng. 2019, 25, 100808. [CrossRef]

20. Alqahtani, F.K.; Ghataora, G.; Khan, M.I.; Dirar, S.; Kioul, A.; Al-Otaibi, M. Lightweight Concrete Containing Recycled Plastic Aggregates. In Proceedings of the 2015 International Conference on Electromechanical Control Technology and Transportation, Paris, France, 13-14 April 2015.

21. Ranjbar, M.M.; Mousavi, S.Y. Strength and durability assessment of self-compacted lightweight concrete containing expanded polystyrene. Mater. Struct. 2015, 48, 1001-1011. [CrossRef]

22. Sadrmomtazi, A.; Dolati-Milehsara, S.; Lotfi-Omran, O.; Sadeghi-Nik, A. The combined effects of waste Polyethylene Terephthalate (PET) particles and pozzolanic materials on the properties of self-compacting concrete. J. Clean. Prod. 2016, 112, 2363-2373. [CrossRef]

23. Nikbin, I.M.; Rahimi, S.; Allahyari, H.; Fallah, F. Feasibility study of waste Poly-Ethylene Terephthalate (PET) particles as aggregate replacement for acid erosion of sustainable structural normal and lightweight concrete. J. Clean. Prod. 2016, 126, 108-117. [CrossRef]

24. Akçaözoglu, S.; Ati s, C.D.; Akçaözoglu, K. An investigation on the use of shredded waste PET bottles as aggregate in lightweight concrete. Waste Manag. 2010, 30, 285-290. [CrossRef]

25. Babafemi, A.; Branko, Š.; Suvash, C.P.; Vivi, A. Engineering Properties of Concrete with Waste Recycled Plastic: A Review. Sustainability. 2018, 10, 3875. [CrossRef]

26. ASTM C642-13. Standard Test Method for Density, Absorption, and Voids in Hardened Concrete; ASTM International: West Conshohocken, PA, USA, 2013.

27. ASTM C1585-13. Standard Test Method for Measurement of Rate of Absorption of Water by Hydraulic-Cement Concretes; ASTM International, West Conshohocken, PA, USA, 2013. 
28. Ruiz-Herrero, J.L.; Nieto, D.V.; López-Gil, A.; Arranz, A.; Fernández, A.; Lorenzana, A.; Merino, S.; De Saja, J.A.; Rodríguez-Pérez, M. Ángel Mechanical and thermal performance of concrete and mortar cellular materials containing plastic waste. Constr. Build. Mater. 2016, 104, 298-310. [CrossRef]

29. CEB-FIP. Diagnosis and Assessment of Concrete Structures-State of Art Report; CEB Bulletin: Lausanne, Switzerland, 1989; Volume 192, pp. 83-85.

(c)

(C) 2019 by the authors. Licensee MDPI, Basel, Switzerland. This article is an open access article distributed under the terms and conditions of the Creative Commons Attribution (CC BY) license (http://creativecommons.org/licenses/by/4.0/). 